NBER WORKING PAPER SERIES

\title{
SUDDEN FLIGHT AND TRUE SUDDEN STOPS
}

\author{
Alexander D. Rothenberg \\ Francis E. Warnock \\ Working Paper 12726 \\ http://www.nber.org/papers/w12726

\section{NATIONAL BUREAU OF ECONOMIC RESEARCH \\ 1050 Massachusetts Avenue} \\ Cambridge, MA 02138 \\ December 2006
}

We thank Jillian Faucette for helpful assistance and comments. We also thank for helpful comments or conversations Rui Albuquerque, Ricardo Caballero, Jeff Frankel, Pierre-Olivier Gourinchas, Marc Lipson, Michael Schill, Martin Schneider, Eric van Wincoop, and seminar participants at Trinity College Dublin and Darden's Financial Economics Workshop. Warnock thanks the Darden School Foundation for generous support. The views expressed herein are those of the author(s) and do not necessarily reflect the views of the National Bureau of Economic Research.

(C) 2006 by Alexander D. Rothenberg and Francis E. Warnock. All rights reserved. Short sections of text, not to exceed two paragraphs, may be quoted without explicit permission provided that full credit, including (C) notice, is given to the source. 
Sudden Flight and True Sudden Stops

Alexander D. Rothenberg and Francis E. Warnock

NBER Working Paper No. 12726

December 2006

JEL No. F32,G15

\title{
ABSTRACT
}

We extend the sudden stops literature by allowing crisis episodes to be caused by either the retreat of global investors, as is assumed but not shown in the extant literature, or the sudden flight of local investors. We find that almost half of the previously defined sudden stops are actually episodes of sudden flight. Compared to sudden flight, true sudden stops are bunched and are associated with greater slowdowns in economic activity and sharper currency depreciations. We show that the empirical regularities of sudden flight and true sudden stops are consistent with theoretical models that incorporate gross capital flows and information asymmetries.

\author{
Alexander D. Rothenberg \\ Department of Economics \\ UC Berkeley \\ Berkeley, CA 94720 \\ alexroth@econ.berkeley.edu \\ Francis E. Warnock \\ Darden Business School \\ University of Virginia \\ Charlottesville, VA 22906-6550 \\ and NBER \\ warnockf@darden.virginia.edu
}




\section{Introduction}

International capital flows can have many benefits for an emerging market economy. For example, foreign flows can result in a reduction in systematic risk (Chari and Henry, 2004) and an increase in both physical investment (Henry 2000, 2003) and economic growth (Bekaert, Harvey, and Lundblad 2001, 2005). Moreover, the act of restraining capital flows can be costly along various dimensions to firms in the emerging market (especially those firms without preferential access to capital) and to the country as a whole (Forbes, 2005). However, any positive aspects of capital flows must be tempered by the fact that their sudden reversal can spark crises. Indeed, the entire literature on sudden stops is focused on identifying and ascertaining the damage caused by crises precipitated by the actions of foreign investors. ${ }^{1}$

The burgeoning sudden stops literature has identified three basic characteristics of this particular type of emerging market crisis. First, sudden stops can inflict a great deal of pain, as they are often accompanied by sharp declines in the exchange rate and in economic activity. Second, sudden stops are not infrequent; an emerging market country can expect to be buffeted by a sudden stop every decade (Edwards, 2005). Third, as noted by virtually all researchers in this literature-including but not limited to Calvo, Izquierdo and Mejia (2004), Frankel and Cavallo (2004), and Mendoza (2006)—sudden stops are caused by foreign investors. Edwards (2005, page 14) succinctly states this last point: “A sudden stop episode (i)s an abrupt and major reduction in capital inflows to a country that up to that time had been receiving large volumes of foreign capital."

In the face of the frequent pain brought on by foreign investors, it is not surprising that prominent academics (Rodrik, 1998; Stiglitz, 2000) question the benefits of financial globalization. Moreover, emerging market policy makers, faced with such a world, cannot be

\footnotetext{
${ }^{1}$ See, among many others, Dornbusch, Goldfajn, and Valdes (1995), Calvo (1998), and Mendoza and Smith (2006).
} 
faulted if they consider erecting walls around their financial systems. A natural policy response to frequent pain imposed by foreigners is to limit their access to local markets.

The primary goal in this paper is to address one very simple question: To what extent are crises, as identified in the sudden stops literature, brought on by the actions of local investors rather than foreign ones? We tackle this question by extending the extant literature to incorporate the actions of local investors. Capital flight is, of course, not unknown to academics and policy makers—see, among others, Dooley (1988), Khan and Ul Haque (1985), and Lessard and Williamson (1987)—but is absent in the current wave of research on sudden stops. ${ }^{2}$ Our analysis indicates that nearly half the crises episodes established by the sudden stops literature are actually episodes of sudden flight in which those who are exiting the market are, to a large extent, local investors.

The extant sudden stops literature lumps episodes of sudden flight together with what we call true sudden stops because, while described in terms of gross capital inflows, in practice sudden stops are identified using data on net capital flows. Because the data are of net flows, so too are theoretical models—incorporating gross flows would be an unnecessary complication. ${ }^{3}$ The sudden stops literature conjures up a scene in which gross capital inflows dry up, but in practice extant analyses combine the actions of local investors with those of foreigners.

We find that a substantial portion of traditionally defined sudden stops episodes are actually sudden flight. After following the literature to identify episodes, we define sudden flight as an episode in which gross capital outflows increase more than gross capital inflows decrease. As it is built from relatively blunt quarterly data on gross capital flows, our measure likely

\footnotetext{
${ }^{2}$ The reader who has not noticed this wave can consult any of the 35 NBER working papers issued since January 2004 that contain 'sudden stop(s)' in the abstract. By contrast, over that period only 7 NBER papers contained the word 'flight' in the abstract, and all but one of those concerned flight-to-quality.

${ }^{3}$ Or maybe the causation is reversed. Traditional international macro models incorporate net flows, so there was no impetus to search beyond net flows to the gross components.
} 
understates the incidence of sudden flight. For example, some episodes that have been described in case studies to be flight_-for example, the Frankel and Schmukler (1996) analysis of the Mexican crisis and the Auguste, Dominguez, Kamil and Tesar (2006) study of the Argentine Corralito episode-will appear to be true sudden stops. ${ }^{4}$ That said, our measure shows that almost half (24) of the 55 episodes are sudden flight in which domestic investors' flight to global capital markets exceeds the slowdown in global investors' flows into the crisis country. These are not situations in which emerging markets are cut off from global capital markets. Rather, the emerging market investors have ample access and utilize it by moving their funds abroad. We then show that, compared with sudden flight, true sudden stops are associated with more pronounced slowdowns in GDP and sharper currency depreciations. In addition, true sudden stops are bunched, which is supportive of a contagion effect, while episodes of sudden flight are more dispersed.

Our results suggest that the extant theoretical literature on sudden stops should also be reevaluated. Most analyses of sudden stops are placed in the realm of net capital flows and utilize traditional international macroeconomic models, such as real business cycle and new open economy macro models. While net capital flows are clearly an important concept, we live in a world of substantial two-way gross capital flows and sudden stops, being a trading phenomenon, should be framed in a trading model that incorporates information asymmetries and gross flows. We show that the Brennan and Cao (1997) dynamic generalization of the multiasset noisy rational expectations model of Admati (1985), after relaxing some assumptions, is well-suited for framing true sudden stops in a way that also allows for sudden flight. In the model sudden flight

\footnotetext{
${ }^{4}$ It is also possible that some of the investments implemented by locals actually to decisions made by global investors. For example, the Chilean episode of 1998 owes, in part, to a shift in bank deposits from Chilean to foreign banks, but there is some evidence that Spanish parent companies were behind this shift. We thank Ricardo Caballero for bringing this to our attention.
} 
can occur if informed locals with superior information foresee a negative shock to the local market and in anticipation shift money to global markets. Net inflows decline, but the decline is prompted not by global investors. True sudden stops (and contagion) can occur if global investors sell emerging market assets when they receive a negative signal that could well originate from the actions of other global investors.

Our study is important for at least three reasons. First, theory is progressing on the assumption that during a sudden stop the emerging market is cut off from global capital markets. Mendoza (2006) discusses dynamic stochastic general equilibrium models that can match the empirical regularities of sudden stops. In motivating his search for appropriate models, Mendoza notes that real business cycle and new open economy macro models-models that have traditionally allowed for net, not gross, capital flows - are not up to the task, in part because "just when the dominant paradigms predict that agents need capital markets the most, agents cannot borrow at all." Caballero and Panageas (2005) predicts the likelihood of sudden stops in which emerging markets are required "at a moment's notice...to reverse the capital inflows that supported the preceding boom." To the extent that theory is validated by matching its predictions to the empirical stylized facts, getting those facts correct is vital.

Second, empirical work is currently searching for preconditions that make countries more (or less) prone to sudden stops. The nascent literature on the interaction between openness and sudden stops appears, to an outsider, somewhat confusing in that it suggests that more open countries are either more susceptible to sudden stops (Calvo et al., 2004) or less susceptible (Edwards, 2005; Frankel and Cavallo, 2004) and that more open countries either have more 
severe crises (Edwards, 2005) or less severe ones (Edwards, 2004). ${ }^{5}$ If sudden flight is fundamentally different from true sudden stops, the mixing of the two is contaminating analysis. Finally, our study is important because to the extent that theoretical and empirical work on sudden stops will morph into policy prescriptions, the proper identification of these episodes is vital. By lumping flight with stops, the extant literature increases the likelihood of recommending policies that impede global investors, when —at least in the case of flight episodes_-often it is local policies that must be reexamined.

The precursors to our paper include the very recent but substantial literature on sudden stops (described throughout this paper); the older literature on capital flight (mentioned above); as well as two recent papers that have focused on gross flows. Faucette, Rothenberg, and Warnock (2005) showed that a non-trivial portion of a restricted sample of Calvo et al. (2004) sudden stops episodes were brought on by the flight of domestic investors, while Cowan and De Gregorio (2005) presents a very informative case study of Chilean gross flows.

The paper proceeds as follows. In the next section, we present empirical regularities of stops and flight episodes by defining empirically true sudden stops and sudden flight, describing the evolution of gross flows around both types of episodes, and characterizing stops and flight by examining the reaction of economic activity and the exchange rate during both types of episodes. In Section 3, we sketch a refocused version of the Brennan and Cao (1997) model of gross capital flows and information asymmetries, which we argue is the type of model that can inform

\footnotetext{
${ }^{5}$ It must be noted that openness is defined differently in these papers. Edwards (2004) uses a trade-to-GDP ratio to measure openness. Frankel and Cavallo (2004) instrument for trade using gravity variables. Calvo et al. (2004) utilize the ratio of tradable to non-tradable goods to define openness. In Edwards (2005), openness is given by a new capital mobility index that is a combination of Quinn (2003), Mody and Murshid (2002), and country-specific information. While the index is designed to provide information on the extent or severity of capital controls, it is used only to place countries in buckets of low, intermediate, and high capital mobility. Analysis is based on groups, not index scores, with the middle group (roughly 140 of the 160 countries) dropped from most of the analysis.
} 
our understanding of true sudden stops and sudden flight. We conclude in Section 4. All data are described in the appendix.

\section{The Stylized Facts}

In this section we establish some stylized facts of sudden flight and true sudden stops. In a true sudden stop, net capital inflows decline because foreigners have exited the emerging market. In a sudden flight, the episode is caused by locals exiting to global markets. Both types of episodes are associated with a sharp decrease in net capital inflows.

\subsection{Defining an Episode}

We follow the sudden stops literature in defining crisis episodes, which we later separate into true sudden stops and sudden flight. Following Calvo et al. (2004) we first construct a monthly capital flows proxy, $P_{t}$, computed by subtracting monthly changes in international reserves from the quarterly current account balance, and then define $C_{t}$ to be a 12-month moving sum of lagged values:

$$
C_{t}=\sum_{i=1}^{12} P_{t-i} \quad t=1,2, \ldots, N
$$

We then compute annual changes in $C_{t}$ :

$$
\Delta C_{t}=C_{t}-C_{t-12} \quad t=1,2, \ldots, N
$$


As in the sudden stops literature, $\Delta C_{t}$ is the focus of our indicator. The first month $t$ that $\Delta C_{t}$ falls one standard deviation below its mean is marked as the beginning of an episode. ${ }^{6}$ The episode ends once $\Delta C_{t}$ again exceeds one standard deviation below its mean. In addition, within the episode, there must be at least one time $t$ when $\Delta C_{t}$ falls at least two standard deviations below its mean.

Figure 1 depicts how the standard sudden stop indicator is constructed for one country (Argentina). The solid line plots $\Delta C_{t}$, with one and two standard deviations below the mean depicted by the upper and lower dashed lines. For example, in 1995 Argentina experienced a decrease in net capital inflows. The episode begins once net inflows fall one standard deviation below the historical mean, providing net capital inflows eventually fall below the two standard deviation line. In this case net inflows did continue to fall. Note that the criteria do not require flows to reverse to net outflows, just that net flows decline. The episode ends when net inflows rise above the one standard deviation line.

To construct these indicators, we gather underlying data on exports, imports, and reserves from the IMF's International Financial Statistics Database (IFS) or from Haver Analytics if IFS data are unavailable or incomplete. We search across a broad set of 28 emerging markets; our data enable us to create indicators which span the period from 1989 through 2005 . We find that among these 28 countries, 70 episodes occurred over the sample period. That is, on average over the 16 -year period we study, each country was inflicted by a crisis episode 2.5 times. Crises, so defined, are not infrequent.

\footnotetext{
${ }^{6}$ We compute rolling means and standard deviations that for month $t$ incorporate all data from January 1987 to month $t$. Following Calvo et al. (2004), we require 24 months of data; thus our indicators begin tracking countries in January 1989. Our last data point is December 2005.
} 


\subsection{Differentiating between Sudden Flight and True Sudden Stops}

Up to this point, our episode characterization is standard and not different in spirit from Calvo et al. (2004) or Frankel and Cavallo (2004). We now break from the extant literature and differentiate between episodes that were true sudden stops of inflows and those that owe to sudden flight. To differentiate between the two, we require somewhat more detailed balance of payments (BOP) data on gross capital flows.

We term an episode a sudden flight if it owed primarily to local residents sending their money abroad. Specifically, a sudden flight is one in which the increase in gross financial outflows from $t_{\mathrm{e}}=-3,-2,-1,0$ to $t_{\mathrm{e}}=1,2,3,4$ is greater than the decrease in gross financial inflows over the same period. In contrast, in a true sudden stop, which owes primarily to the actions of global investors; the decrease in gross inflows exceeds the increase in gross outflows. ${ }^{7}$

Excluding episodes with missing BOP data-in 15 cases we were unable to find data on gross capital flows-leaves us with 55 episodes that occurred in 24 emerging markets (Table 1). Of the 55 episodes, we found that 31 were indeed true sudden stops, but 24 were sudden flight. On average, over our 16-year sample period each country was inflicted by a true sudden stop 1.3 times and by sudden flight once. True sudden stops are less frequent than portrayed in the literature.

Our method likely understates the proportion of episodes that were triggered by sudden flight. For example, we utilize data on reported financial flows. Large negative net errors and omissions during crises are likely indicative of unreported financial outflows; not knowing this for certain, we rely only on reported financial flows. Moreover, some episodes that have been

\footnotetext{
${ }^{7}$ Note that episodes are first identified using net flows data before gross flows data are used to separate flight from stops. An alternative way to define true sudden stops and sudden flight might begin with the gross flows data. This alternative, while potentially appealing, has at least two drawbacks. First, in the end it is net flows that matter. For example, a surge in gross outflows when inflows are sizeable is not generally thought of as a crisis; it is usually called international portfolio diversification. Second, gross flows data for emerging markets are not up to the task in terms of frequency, completeness, and quality.
} 
shown using case studies to have been prompted by the flight of locals appear as sudden stops using blunt quarterly BOP data on gross flows. An example is the 1994 Mexican Peso Crisis, which was shown by Frankel and Schmukler (1996) to be triggered by the flight of local investors. However, it is a sudden stop using our coding technique because the sheer size of the retrenchment by foreigners (once they took the signal from the locals) far exceeded the magnitude of local flight. A more recent example is the flight from Argentina in 2001 (see Auguste et al. 2006), which is also a true sudden stop using our methodology. Case studies will always be able to drill down more deeply into any single episode.

\subsection{Characteristics of Sudden Flight and True Sudden Stops}

\section{Gross Capital Flows}

Figure 2 depicts the evolution of gross capital inflows for all episodes (Fig. 2a), true sudden stops (Fig. 2b), and episodes of sudden flight (Fig. 2c). Across traditionally defined episodes, gross financial inflows fall sharply, but they rebound very quickly. ${ }^{8}$ This quick resumption of inflows is clearly not what the sudden stops literature is built on-even the strongest countries can face a one-quarter pause in gross inflows. For true sudden stops, as the literature suggests, gross inflows drop off considerably and remain modest for a full year, the painful period during which the emerging market economy is starved for capital but receives none. Episodes of sudden flight are also characterized by a slowdown in inflows, but here the slowdown is only temporary and is followed by very strong inflows for the next two years. ${ }^{9}$

\footnotetext{
${ }^{8}$ To be included in a figure an episode must have complete data for the entire sample depicted. For example, in Figure 2, we have only 47 episodes because inclusion requires 8 quarters of gross flows data before and after the beginning of an episode. The figure is compiled using means; the contours of gross inflows are very similar if we use medians (not shown).

${ }^{9}$ Sudden flight episodes are counted as episodes in the existing literature because the temporary slowdown in inflows is accompanied by a surge in outflows.
} 


\section{Bilateral Securities Positions vis-à-vis the United States}

Figure 3 provides another view of the distinction between flight (dashed lines) and true stops (solid lines). The figure shows the evolution of U.S. investors' positions in the inflicted countries' stocks and bonds (left side), as well as these countries' positions in U.S. equities and bonds (right side). During a sudden flight, U.S. investors increase their positions in emerging market equities and, to a lesser extent, bonds, while local investors increase their positions in U.S. securities. During a true sudden stop, U.S. investors decrease their positions in the emerging market securities, first in equities but later in bonds, too.

\section{Severity and Time Bunching}

We next attempt to determine if there are substantial differences between stops and flight by examining the performance of real GDP, its components, and the currency before, during, and after each episode. Compared to sudden flight episodes, true sudden stops are accompanied by larger slowdowns in overall GDP as well as consumption and investment (Figure 4). For example, in the four quarters following the onset of a true sudden stop, GDP growth slows to near zero, whereas the slowdown during sudden flight is modest. For stops, the slowdown owes to declines in consumption and investment that are not offset by the surge in net exports. The figure does not portray the considerable variation within each type of episode, but graphs using medians (not shown) are similar and, at the 10\% level, growth in GDP, consumption, and imports is significantly lower in stops than in flight episodes. True sudden stops are painful. ${ }^{10}$

\footnotetext{
${ }^{10}$ Recently, many researchers in the sudden stops literature have followed the lead of Calvo et al. (2004) and begun to impose the additional ad hoc requirement that the episode must be painful, where 'pain' is defined as an absolute drop in GDP during the sudden stop episode. Our work suggests that true sudden stops are painful, so there is no need to impose pain in an ad hoc way.
} 
True sudden stops are also accompanied by a sharp depreciation of the nominal exchange rate (Figure 5). ${ }^{11}$ In contrast, at the onset of sudden flight the currency depreciation is quite muted, although depreciations are slightly larger leading into it. Most of the dramatic change in the exchange rate owes to two countries (Argentina and Brazil); median changes are more muted and the difference between stops and flight is not significant at the $10 \%$ level. Figures 4 and 5 are not unrelated: To the extent that emerging markets have difficulties borrowing in their local currency (Eichengreen and Luengnaruemitchai, 2004; Burger and Warnock 2006a, 2006b), the depreciation has immediate balance sheet effects that will adversely impact economic activity (Calvo et al., 2004; Mendoza and Smith, 2006).

Figure 6 plots the time-bunching of sudden stops episodes by the type of episode. True sudden stops are bunched from 1997 through 2001. In contrast, sudden flight episodes appear to be isolated across time. These charts are suggestive of a world in which true sudden stops have an important common component — and that perhaps for them contagion is an apt descriptorwhereas sudden flight episodes are more likely driven by local conditions.

\section{A Model of Flight and Stops}

The literature on sudden stops utilizes various international macro models, from real business cycle to new open economy macro to debt-deflation models; see Mendoza (2006) for a useful summary. However, the stylized facts suggest that these crisis episodes are best framed in the context of the canonical model of gross flows and information asymmetries: the Brennan and Cao (1997) dynamic generalization of the multiasset noisy rational expectations model of Admati (1985). While the focus of Brennan and Cao (1997) was not on sudden stops but rather

\footnotetext{
${ }^{11}$ Movements in real exchange rates (not shown) are very similar because changes in relative inflation rates are minimal.
} 
on the returns-chasing behavior of U.S. investors, ${ }^{12}$ we present a version of their model (with a slight re-emphasis and slightly different assumptions) that can inform our understanding of sudden stops and sudden flight.

In the model, country of residence matters. There are $M$ risky assets, each of which can be thought of as being a country's equity index. Each risky asset has a terminal payoff realized at time 1 given by an $M x 1$ normally distributed random vector $\tilde{U}$ that has mean $\bar{U}$ and precision matrix $H$. Everyone has access to a riskless interest rate of zero. An investor in country $i$, $i \in[0,1]$, is endowed at time 0 with quantities of the risky assets given by the vector $X^{i}$. The investors have exponential utility functions defined over time 1 terminal consumption with common CARA of $1 / r$. The vector of aggregate per capita supply of the risky assets, $\tilde{X}_{0}$, is normally and independently distributed with mean $\bar{X}_{0}$ and precision matrix $\Phi_{0}$. The $T$ trading sessions are held at times $\tau_{\mathrm{t}}=t / T, t=0, \ldots, T-1$, and at time 1 asset payoffs are realized and consumption takes place.

Prior to trading session $t$, each investor $i$ gets an $M x l$ vector of private signals $\tilde{Z}_{t}^{i}$ about the asset payoffs:

$$
\tilde{Z}_{t}^{i}=\tilde{U}+\widetilde{\varepsilon}_{t}^{i}
$$

where $\widetilde{\varepsilon}_{t}^{i}$ is distributed normally and independently of $\tilde{U}$, has mean zero, and is independent of $\widetilde{\varepsilon}_{j}^{k}$ if $\mathrm{k} \neq \mathrm{i}$ or $\mathrm{j} \neq \mathrm{t}$. The precision matrix of private signals received by investor $i$ just before session $t$ is denoted by $S_{t}^{i}$.

\footnotetext{
${ }^{12}$ For more recent empirical evidence on the trading behavior of U.S. investors, see Thomas, Warnock, and Wongswan (2006) and Albuquerque, Bauer, and Schneider (2006).
} 
Prior to trading session $t=0, \ldots, T-1$ each investor $i$ gets an $M x l$ vector of public signals $\tilde{Y}_{t}$ about the asset payoffs:

$$
\tilde{Y}_{t}=\tilde{U}+\tilde{\eta}_{t}
$$

where $\widetilde{\eta}_{t}$ is distributed normally with mean zero and precision matrix $N_{t}$. It is assumed that $N_{0}=N_{T}^{-1}=0$, where 0 is the zero matrix. There is no public information at time $0\left(\tilde{Y}_{0}=0\right)$ and all risky asset returns are realized at session $T$.

New liquidity traders enter the market in each trading session $t=1, \ldots, T-1$. The incremental net supply of liquidity traders is given by the normally distributed random vectors, $\tilde{X}_{t}$, which have means $\bar{X}_{t}$ and precision matrices $\Phi_{\mathrm{t}}$. Let $\bar{X}_{t}=0$ for $t>0$, and assume that the total trading volume is not observable by traders (to preserve the less than fully revealing nature of the rational expectations equilibrium).

Letting $\widetilde{P}_{t}$ denote the vector of equilibrium risky asset prices and $\widetilde{D}_{t}^{i}$ denote the vector of risky asset demands for investor $i$ in trading session $t$, then solution techniques of Admati (1985) and Brennan and Cao (1997) can be used to show that the optimal trading strategy of investor $i$ is

$$
\Delta \tilde{D}_{t}^{i} \equiv \tilde{D}_{t}^{i}-\tilde{D}_{t-1}^{i}=r\left[S_{t}^{i}\left(\tilde{Z}_{t}^{i}-\tilde{P}_{t}\right)-S_{t}\left(\tilde{U}-\tilde{P}_{t}\right)+\frac{\tilde{X}_{t}}{r}-\sum_{j=0}^{t-1}\left(S_{j}^{i}-S_{j}\right) \Delta \tilde{P}_{t}\right]
$$

That is, investor $i$ 's trading strategy depends on 
a) $S_{t}^{i}\left(\tilde{Z}_{t}^{i}-\tilde{P}_{t}\right)$ : The difference between his vector of private signals in period $t$ and the vector of prices, weighted by his private signal precision matrix;

b) $-S_{t}\left(\tilde{U}-\tilde{P}_{t}\right)$ : The difference between the vector of the average private signal and the vector of prices, weighted by the average private signal precision matrix;

c) the vector of supply shocks due to new liquidity trades; and

d) $-\sum_{j=0}^{t-1}\left(S_{j}^{i}-S_{j}\right) \Delta \tilde{P}_{t}:$ the (negative of the) vector of price changes, weighted by the difference between the investor's private signal precision matrix and the market average precision matrix (accumulated for all sessions up to session $t-1$ ).

Points (a) and (b) together yield $S_{t}^{i}\left(\tilde{Z}_{t}^{i}-\tilde{P}_{t}\right)-S_{t}\left(\tilde{U}-\tilde{P}_{t}\right)$, which shows that investor $i$ will buy in markets for which he receives a private signal that is stronger than the average investors' private signal (as long as his signal is sufficiently precise). Point (d) shows that investors will follow momentum strategies in countries in which they have a cumulative information disadvantage; if $S_{j}^{i}<S_{j}$ then investor $i$ will chase price movements, buying when prices increase and selling when prices decline.

To focus on the returns-chasing component (point d), Brennan and Cao (1997) imposed that information endowments are symmetric. The symmetry assumption imposed that the elements of an investor's precision matrix do not differ across foreign markets (and can be zero); with this assumption, trades are a function only of market returns. In contrast, we allow for a role for (a) and (b) and thus allow for asymmetric information across foreign markets.

We next focus on the implications of the model for a particular emerging market $e$ and a country $g$ with global investors. Consider first the trades of global investors in the emerging 
market. Abstracting from liquidity trades, the global investor's trading in the emerging market's assets will be governed by the Information Trade and Returns-Chasing. The Information Trade in this case is given by

$$
S_{e, t}^{g}\left(\tilde{Z}_{e, t}^{g}-\tilde{P}_{e, t}\right)-S_{e, t}\left(\tilde{U}_{e}-\widetilde{P}_{e, t}\right)
$$

The global investor will buy emerging market assets if he receives a stronger than average positive signal about $e$. Note that this positive $e$ signal can owe to information about strong fundamentals in $e$, or it could be due to a strong, precise negative signal about $g$. It could also, as suggested by Albuquerque et al. (2006), originate from information about the likely actions of other $g$-type investors. This information about other $g$-type investors can be termed a global private signal; the investment business is sufficiently global that it is not unlikely that funds based in America are aware of the likely actions of other global investors. Conversely, global investors will sell emerging market assets if they receive negative news about the emerging market or relatively positive news about other markets. Moreover, they will also sell emerging market assets if they receive a global private signal that other $g$-type investors will sell.

If locals have a cumulative information advantage, also at work is Returns-Chasing:

$$
-\sum_{j=0}^{t-1}\left(S_{e, j}^{g}-S_{e, j}\right) \Delta \tilde{P}_{e, t}
$$


With returns chasing, if $g$ has a cumulative information disadvantage in $e$, then he will buy $e$ on price increases (thinking that someone must have strongly positive private information on $e$ ) and sell $e$ on price declines.

Similar expressions can be derived for emerging market investors' trades in global markets. For instance, an investor from an emerging market will move into global markets when he receives a negative signal about his home market. Which effect dominates-Information Trade or Returns Chasing-depends on the relative magnitudes of the marginal and cumulative information (dis)advantages. ${ }^{13}$

The canonical Brennan and Cao (1997) model predicts that emerging markets are not always culpable for sharp declines in net inflows. Errors in local public and global private signals result in too many inflows when positive and too many outflows when negative. If informed global investors receive a negative global signal, we expect to see outflows from emerging markets that are not associated with local fundamentals. But there are also times during which the locals are behind the outflows. When locals receive a negative local private signal, they head for global markets, selling to foreigners on their way out.

In terms of the sudden stops language, true sudden stops can be caused (i) by global investors recoiling from all markets because of a negative (private) signal about global markets, or (ii) by global investors misinterpreting and overreacting to a perceived negative (public) signal about an emerging market. Sudden flight, in contrast, owes to locals exiting their markets because of a negative (private) signal about the local economy. Another implication is that, relative to episodes of sudden flight, sudden stops should be bunched in time across countries (as Figure 6 showed).

\footnotetext{
${ }^{13}$ For their particular focus, Brennan and Cao (1997) assumes the cumulative (dis)advantage dominates, but we do not require such an assumption.
} 
In summary, the Brennan and Cao (1997) model of information asymmetries and gross flows is consistent with the stylized facts of sudden stops and sudden flight. As such, it is a useful alternative to the classes of models currently used to analyze sudden stops. Sudden stops are trading phenomena that are usefully framed in a trading model.

\section{Conclusion}

Episodes of sudden flight—absent from the burgeoning literature on emerging market crises - can owe to the rational trades of locals who have superior information about upcoming negative news about the local (emerging) market. Empirically, many emerging market crises that were previously categorized as sudden stops of capital inflows are actually sudden flight episodes in which locals exit to global markets. The two types of episodes differ in important ways, with true sudden stops being accompanied by substantially more pain in the form of sharper declines in economic activity and the currency. By distinguishing between flight and stops, future work can provide a better understanding of the conditions that lead to each type of infliction. Moreover, for those who want to focus on true sudden stops, removing sudden flight episodes from their analysis should lead to sharper empirical results and, hence, better informed policy prescriptions.

Many different types of theoretical international macroeconomic models are currently used to study sudden stops. Our hope is that our work prompts researchers in this impressive literature to incorporate gross flows in their models. 


\section{References}

Admati, A., 1985. A noisy rational expectations equilibrium for multi-asset securities markets. Econometrica 53: 629-657.

Albuquerque, R., G. Bauer, and M. Schneider, 2006. Global private information in international equity markets. mimeo.

Auguste, S., Dominguez, K., Kamil, H., Tesar, L., 2006. Cross-border trading as a mechanism for implicit capital flight: ADRs and the Argentine crisis. Journal of Monetary Economics, forthcoming.

Bekaert, G., C. Harvey, and C. Lundblad, 2001. Emerging equity markets and economic development. Journal of Development Economics 66: 3-465-504.

2005. Does financial liberalization spur growth?

Journal of Financial Economics 77: 3-56.

Brennan, M., and H. Cao, 1997. International portfolio investment flows. Journal of Finance 52(5): 1851-18880.

Burger, J., and F. Warnock, 2006a. Local currency bond markets. IMF Staff Papers 53: 115-132. ,2006b. Foreign participation in local currency bond markets. Review of Financial Economics (forthcoming).

Cabellero, R., and S. Panageas, 2005. A quantitative model of sudden stops and external liquidity management. NBER Working Paper 11293.

Calvo, G., 1998. Capital flows and capital-market crises: the simple economics of sudden stops. Journal of Applied Economics 1(1): 35-54.

, A. Izquierdo, and L. Mejía, 2004. On the empirics of sudden stops: the relevance of balance-sheet effects. NBER Working Paper 10520.

Chari, A., and P. Henry, 2004. Risk sharing and asset prices: evidence from a natural experiment. Journal of Finance 59(3): 1295-1324.

Cowan, K., and J. De Gregorio, 2005. International borrowing, capital controls and the exchange rate lessons from Chile. NBER Working Paper 11382.

Dooley, M., 1988. Capital flight: a response to differences in financial risks. IMF Staff Papers 35: 422-436.

Dornbusch, R., I. Goldfajn, and R. Valdes, 1995. Currency crises and collapses. Brookings Papers on Economic Activity 0(2): 219-70. 
Edwards, S., 2004. Thirty years of current account imbalances, current account reversals, and sudden stops. IMF Staff Papers 51: 1-49.

,2005. Capital controls, sudden stops and current account reversals. NBER Working Paper 11170.

Eichengreen, B., and P. Luengnaruemitchai, 2004. Why doesn't Asia have bigger bond markets? NBER Working Paper 10576.

Faucette, J., A. Rothenberg, and F. Warnock, 2005. Outflows-induced sudden stops. Journal of Policy Reform 8(2): 119-130.

Forbes, K., 2005. The micro evidence on capital controls: no free lunch. NBER Working Paper 11372.

Frankel, J., and E. Cavallo, 2004. Does openness to trade make countries more vulnerable to sudden stops, or less? Using gravity to establish causality. NBER Working Paper 10957.

, and S. Schmukler, 1996. Country fund discounts and the Mexican crisis of December 1994. Open Economies Review 7.

Henry, P., 2000. Do stock market liberalizations cause investment booms? Journal of Financial Economics 58: 301-334.

,2003. Capital account liberalization, the cost of capital, and economic growth. American Economic Review 93(2): 91-96.

Khan, M., and N. Ul Haque, 1985. Foreign borrowing and capital flight: a formal analysis. IMF Staff Papers 32: 606-628.

Lessard, D., and J. Williamson, 1987. Capital Flight and Third World Debt. Washington: Institute for International Economics.

Mendoza, E., 2006. Lessons from the debt-deflation theory of sudden stops. NBER Working Paper 11966.

, and K. Smith, 2006. Quantitative implications of a debt-deflation theory of Sudden Stops and asset prices. Journal of International Economics 70(1): 82-114.

Mody, A., and A. Murshid, 2002. Growing up with capital flows. IMF Working Paper WP/02/75.

Quinn, D., 2003. Capital account liberalization and financial globalization, 1890-1999: a synoptic view. International Journal of Finance and Economics 8(3): 189-204. 
Rodrik, D., 1998. Who needs capital account convertibility? Essays in International Finance No. 207 (Princeton: Princeton University Press).

Stiglitz, J., 2000. Capital market liberalization, economic growth and instability. World Development 25: 1075-1086.

Thomas, C., F. Warnock, and J. Wongswan, 2006. The performance of international equity portfolios. NBER Working Paper 12346. 


\section{Appendix: Description of Data}

We rely on the IMF's International Financial Statistics (IFS) where possible. Specifically, we utilize IFS data on the current account balance (line 78ald), exports (line 78aad), imports (line 78abd), international reserves (line 11.d), and the nominal exchange rate (line rf).

In addition, we gather data on gross flows from IFS. In keeping with BOP accounting, the term Inflows refers to the net purchases by foreigners of the country's securities, instruments, or firms, while Outflows refers to the net purchases by the country's residents of foreign securities, instruments, or firms. Because in BOP accounting outflows are reported with a negative sign, we multiply outflows by negative one to obtain the magnitude of gross outflows. Specifically, gross inflows and outflows are defined as

Gross Financial Inflows = Inflows of FDI (IFS line 78bed) + Portfolio Debt and Equity Inflows (IFS line 78bgd) + Other Investment Inflows (IFS line 78bid)

Gross Financial Outflows $=-[$ Outflows of FDI (IFS line 78bdd) + Portfolio Debt and Equity Outflows (IFS line 78bfd) + Other Investment Outflows (IFS line 78bhd)]

U.S. investors' positions in the country's securities and the country's positions in U.S. securities are constructed as in Thomas, Warnock, and Wongswan (2006).

For data on real GDP and its components, we rely on estimates produced by individual country statistical agencies and compiled by Haver Analytics. These series often have longer samples than those from IFS and generally have better coverage of components. The GDP data are seasonally adjusted, and we take percent changes at annual rates for use in our severity comparisons.

In all cases, when missing values exist in the current IFS data set, we turn to Haver Analytics databases to search for the replacement data. 
Table 1. Descriptive Statistics of Sudden Stop Episodes

The table shows for all episodes the dates, the change in gross outflows and gross inflows for the one year leading up to and following the onset of the episodes, and whether the episodes is a true sudden stop (TSS) or sudden flight (SF).

\begin{tabular}{|c|c|c|c|c|c|}
\hline \multirow{3}{*}{ 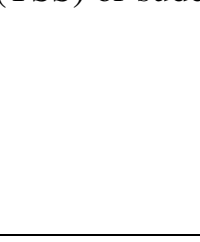 } & \multicolumn{2}{|c|}{ Timing of Episode } & \multicolumn{2}{|c|}{$\begin{array}{l}\text { Change in Gross Capital Flows from } t_{e}=-3,- \\
\qquad 2,-1,0 \text { to } t_{e}=1,2,3,4\end{array}$} & \\
\hline & \multirow{2}{*}{ Start Date } & \multirow{2}{*}{ End Date } & Gross Outflows & Gross Inflows & \\
\hline & & & \multicolumn{2}{|c|}{ (Billions of USD) } & \\
\hline Argentina I & Mar-89 & Jan-90 & 1.28 & -7.17 & TSS \\
\hline Argentina II & Jan-95 & Dec-95 & 6.76 & -0.17 & $\mathrm{SF}$ \\
\hline Argentina III & Aug-99 & Nov-99 & -1.66 & -5.45 & TSS \\
\hline Argentina IV & Mar-01 & Oct- 02 & -1.67 & -24.49 & TSS \\
\hline Brazil I & Mar-93 & Nov-93 & 3.56 & 5.27 & $\mathrm{SF}$ \\
\hline Brazil II & Feb-95 & Jun-95 & -4.35 & 16.93 & SF \\
\hline Brazil III & Jan-97 & Jun-97 & -3.99 & -12.50 & TSS \\
\hline Brazil IV & Jan-99 & Aug-99 & -3.48 & -15.40 & TSS \\
\hline Chile I & Jul-91 & Apr-92 & -1.45 & 1.01 & TSS \\
\hline Chile II & Oct-95 & Aug-96 & 1.19 & 1.84 & $\mathrm{SF}$ \\
\hline Chile III & Jun-98 & Jul-99 & 5.61 & -1.23 & SF \\
\hline Chile IV & Jan-04 & Mar-05 & 2.83 & -0.44 & $\mathrm{SF}$ \\
\hline Colombia II & Apr-98 & Jun-00 & -0.02 & -2.78 & TSS \\
\hline Czech Rep & Jan-97 & Mar-97 & 2.04 & -1.04 & $\mathrm{SF}$ \\
\hline Greece IV & Oct-99 & Mar-01 & -7.48 & -1.92 & TSS \\
\hline Hungary & Dec-96 & Jun-97 & 0.97 & -0.51 & $\mathrm{SF}$ \\
\hline India I & May-93 & Sep-93 & -1.23 & 3.19 & $\mathrm{SF}$ \\
\hline India II & May-95 & May-96 & 4.26 & -0.17 & $\mathrm{SF}$ \\
\hline Indonesia I & Oct-92 & Nov-93 & 0.18 & -2.28 & TSS \\
\hline Indonesia II & Dec-97 & Nov-98 & -0.29 & -28.71 & TSS \\
\hline Indonesia III & Dec-99 & Nov-00 & 0.06 & -3.11 & TSS \\
\hline Jordan I & Dec-91 & Jul-92 & -0.23 & -0.80 & TSS \\
\hline Jordan II & Dec-94 & Apr-95 & 0.49 & 0.53 & $\mathrm{SF}$ \\
\hline Jordan III & Oct-98 & Jun-99 & 0.23 & 0.81 & $\mathrm{SF}$ \\
\hline Korea I & Sep-97 & Nov-98 & -11.56 & -55.72 & TSS \\
\hline Korea II & Apr-01 & Dec-01 & -2.60 & 3.17 & $\mathrm{SF}$ \\
\hline Mexico & Apr-94 & Mar-95 & -1.40 & -42.12 & TSS \\
\hline Pakistan I & Sep-95 & Nov-95 & -0.07 & 1.24 & $\mathrm{SF}$ \\
\hline Pakistan II & May-98 & Jan-99 & 0.07 & -3.61 & TSS \\
\hline Pakistan III & Dec-03 & Aug-04 & 0.09 & 0.00 & $\mathrm{SF}$ \\
\hline Peru II & Jul-97 & Feb-98 & 0.15 & -1.13 & TSS \\
\hline Peru III & Feb-99 & Nov-99 & 0.04 & -1.19 & TSS \\
\hline Philippines I & Jun-95 & Oct-95 & 0.02 & 3.99 & $\mathrm{SF}$ \\
\hline Philippines II & Jun-97 & Jul-99 & -4.49 & -10.92 & TSS \\
\hline Philippines III & Jan-00 & Jun-01 & -3.40 & -5.19 & TSS \\
\hline Poland I & Jan-90 & Sep-90 & 4.39 & -2.72 & $\mathrm{SF}$ \\
\hline Portugal I & Jan-89 & May-89 & -1.16 & 2.55 & SF \\
\hline Portugal II & Mar-91 & Aug-91 & -0.63 & 1.34 & $\mathrm{SF}$ \\
\hline Portugal III & Oct-92 & Oct-93 & 6.23 & 0.75 & $\mathrm{SF}$ \\
\hline S. Africa & Nov-96 & Jan-97 & 5.19 & 10.59 & SF \\
\hline Slovak Rep I & Jul-97 & Apr-98 & -1.82 & -0.78 & TSS \\
\hline Slovak Rep II & Apr-99 & Sep-99 & 1.44 & 1.58 & $\mathrm{SF}$ \\
\hline
\end{tabular}




\begin{tabular}{|c|c|c|c|c|c|}
\hline Slovak Rep III & Aug-03 & Jul-04 & 0.98 & -3.89 & TSS \\
\hline Sri Lanka I & Mar-89 & Sep-89 & 0.00 & 0.32 & $\mathrm{SF}$ \\
\hline Sri Lanka II & Feb-95 & Aug-96 & 0.00 & -0.23 & TSS \\
\hline Sri Lanka III & Nov-00 & Feb-01 & 0.02 & -0.74 & TSS \\
\hline Thailand I & Oct-91 & Dec-92 & 0.85 & -3.56 & TSS \\
\hline Thailand II & Dec-96 & Jul-98 & 2.26 & -19.49 & TSS \\
\hline Turkey I & May-91 & Jan-92 & 0.15 & -1.75 & TSS \\
\hline Turkey II & Mar-94 & Jan-95 & -6.28 & -19.43 & TSS \\
\hline Turkey III & Oct-98 & Sep-99 & -11.83 & -2.43 & TSS \\
\hline Turkey IV & Jun-01 & Mar-02 & -0.45 & -13.01 & TSS \\
\hline Venezuela II & Mar-00 & Apr-01 & 0.90 & -1.55 & TSS \\
\hline Zimbabwe I & Nov-93 & Jan-94 & 0.32 & 0.03 & SF \\
\hline Zimbabwe II & Apr-94 & Oct-94 & 0.15 & -0.15 & TSS \\
\hline
\end{tabular}




\section{Figure 1. Indicator Construction}

The figure shows the traditional construction of a sudden stops indicator for Argentina. Shaded areas are episodes, which begin when the capital flows proxy (the solid line) drops one standard deviation below its historical mean (the upper dashed line), provided the proxy eventually falls two standard deviations below its mean (the lower dashed line). The episode ends when the proxy again crosses the one standard deviation line.

Figure 1

Sudden Stops Indicator Construction: Argentina (213)

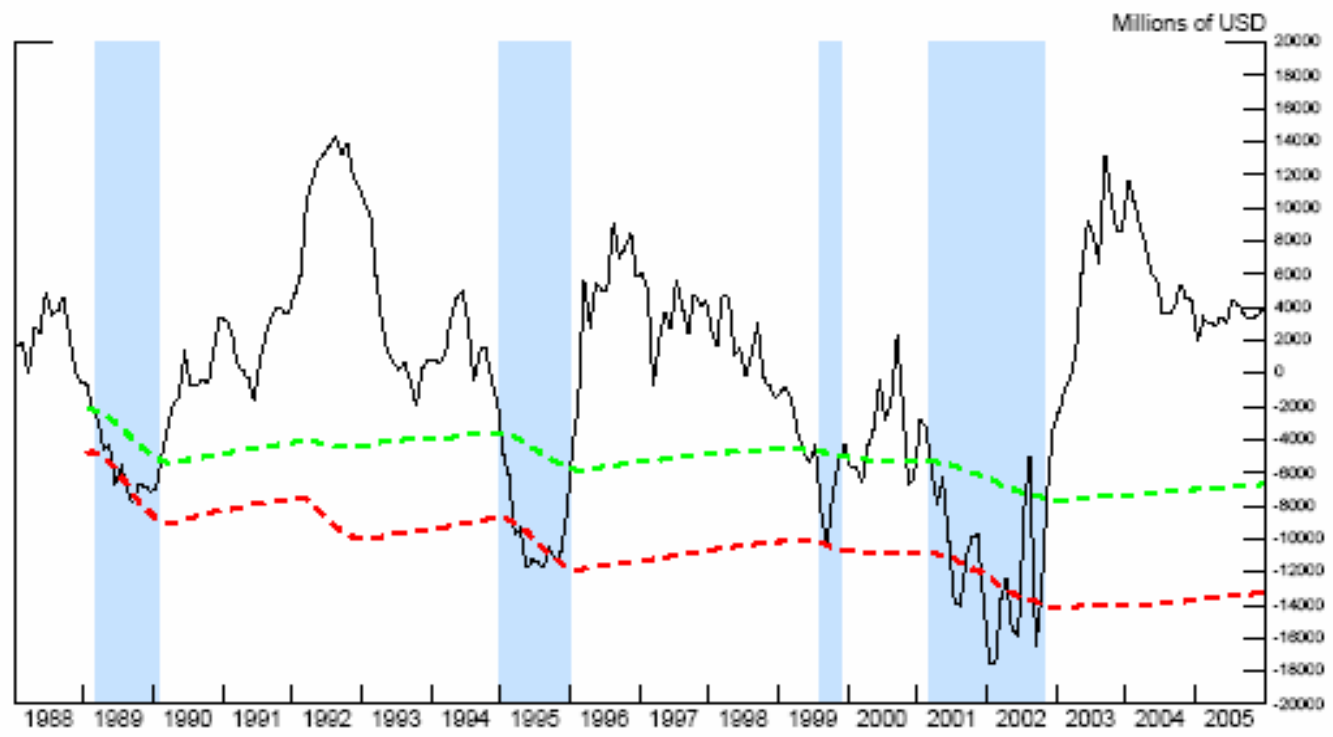


Figure 2. Gross Inflows During All Episodes, True Sudden Stops, and Sudden Flight

The figures depict mean gross inflows during 47 episodes (27 true sudden stops and 20 sudden flight). Event time is in quarters, with zero being the beginning of the episode.

(a) All Episodes

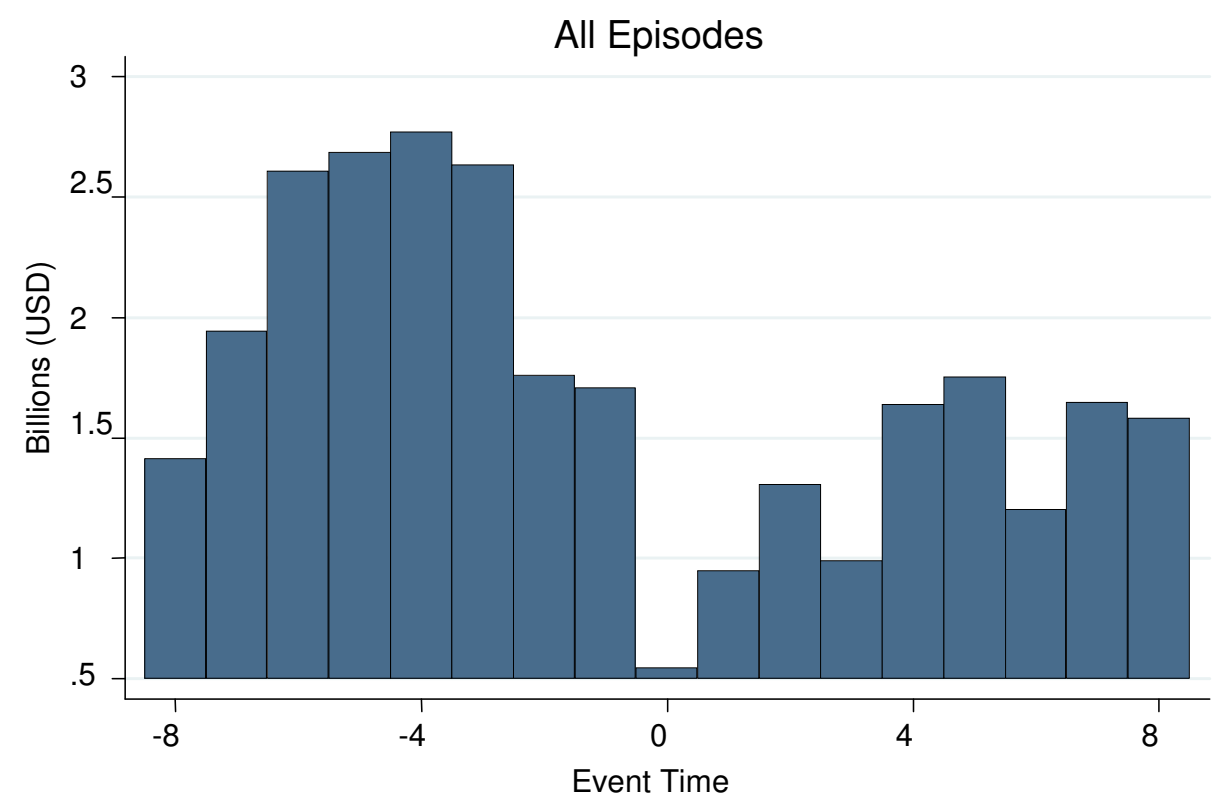

(b) True Sudden Stops

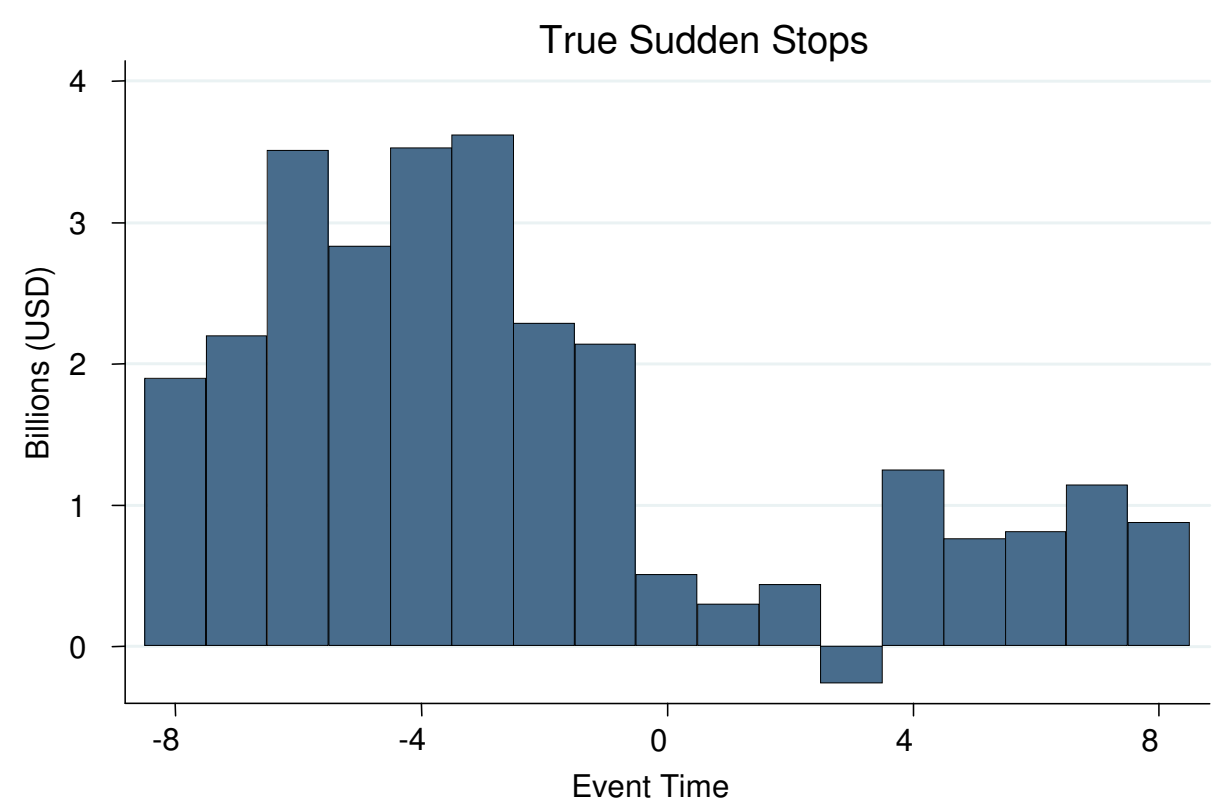


(c) Sudden Flight

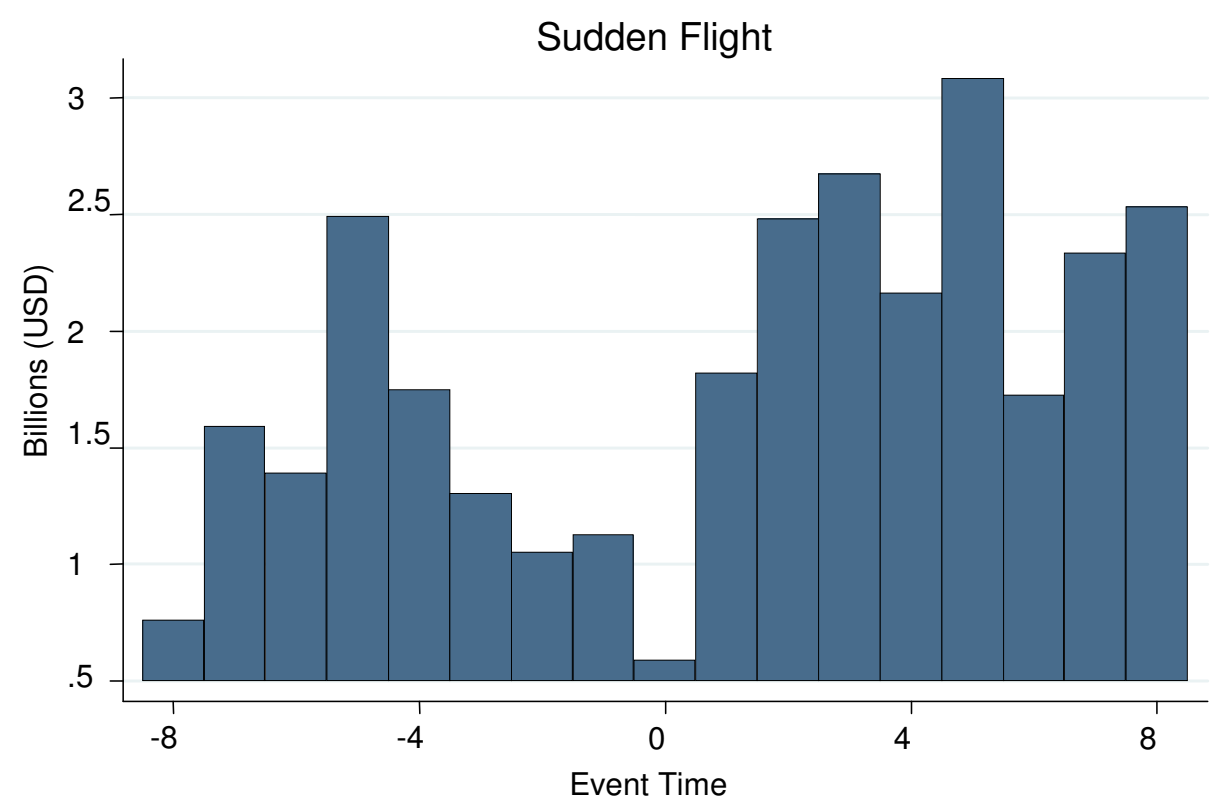


Figure 3. Evolution of Bilateral Positions in Equities and Bonds

The figures depict mean quarterly changes in U.S. positions in inflicted countries and those countries' positions in U.S. securities during 27 true sudden stops (solid lines) and 20 sudden flight episodes (dashed lines). Bilateral positions data are constructed as in Thomas, Warnock, and Wongswan (2006).
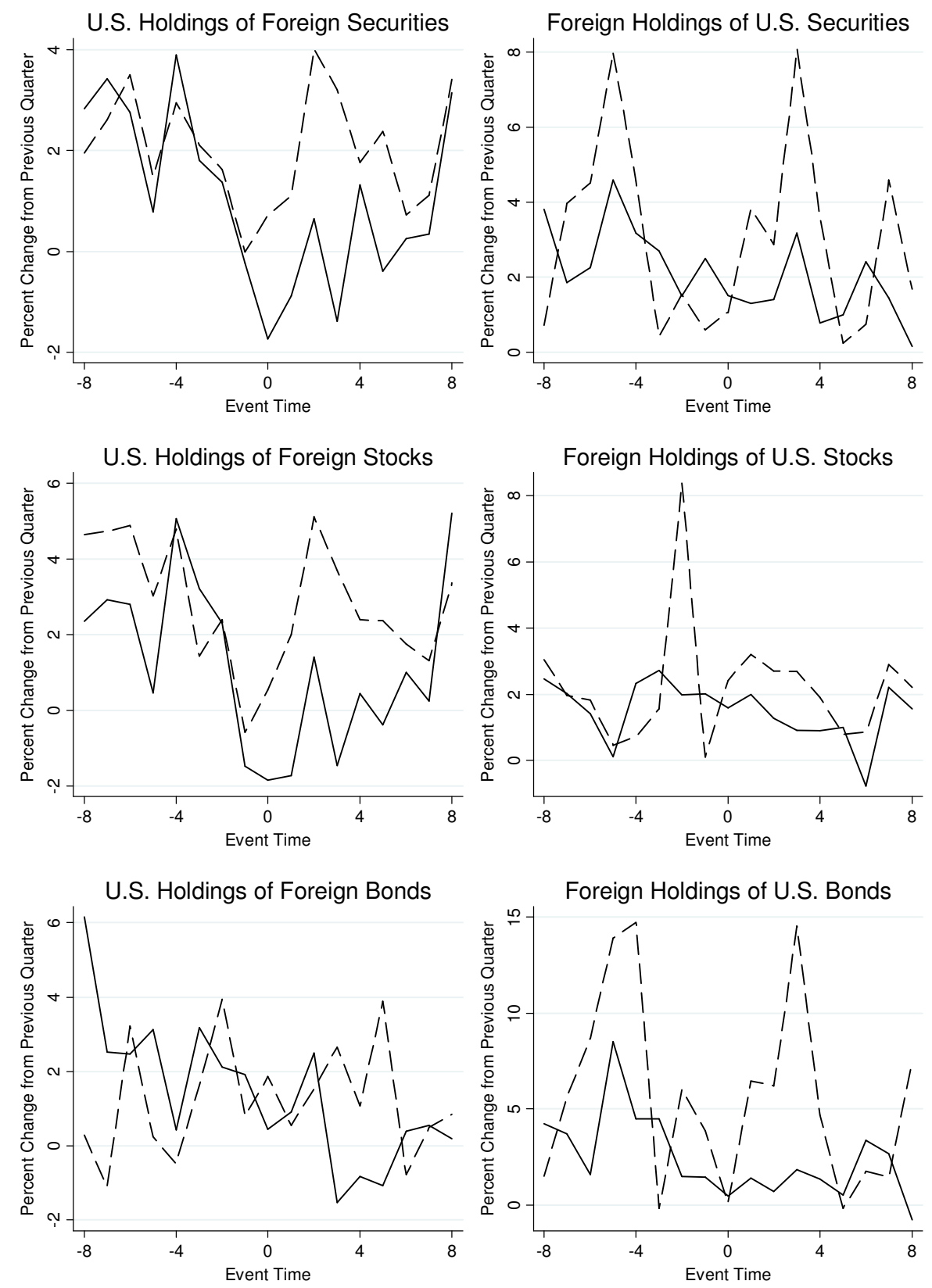
Figure 4. Evolution of GDP and its Components

The figures depict mean year-over-year changes in real GDP and its components during 24 true sudden stops (solid lines) and 13 sudden flight episodes (dashed lines). Data availability limits the sample sizes in the components graphs; the smallest samples are for consumption (22 stops and 6 flight).
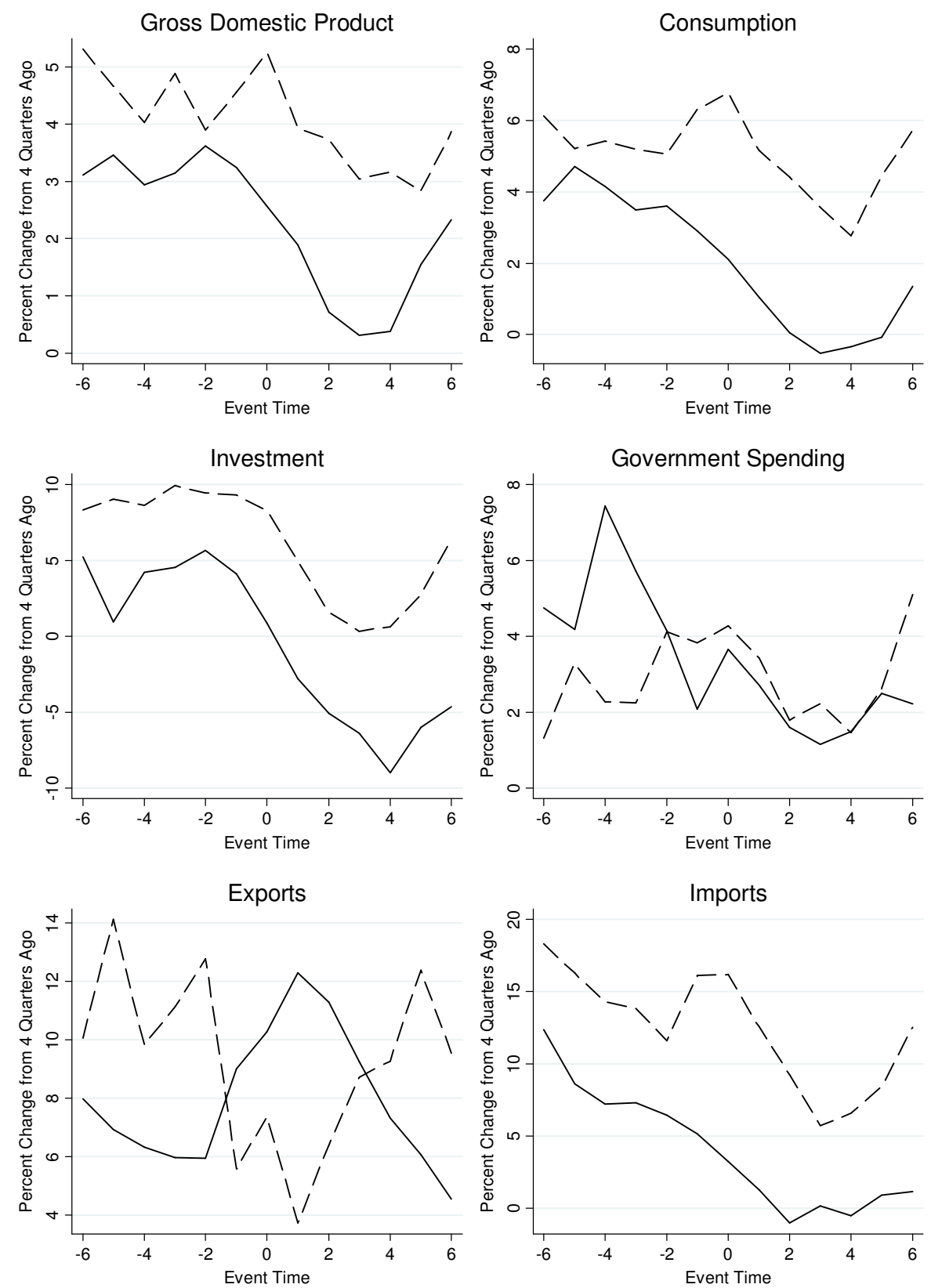
Figure 5. Evolution of Exchange Rate

The figure depicts mean quarterly changes in the nominal exchange rate, defined as local currency per U.S. dollar (up is depreciation), during 30 sudden stops (solid line) and 24 sudden flight episodes (dashed line).

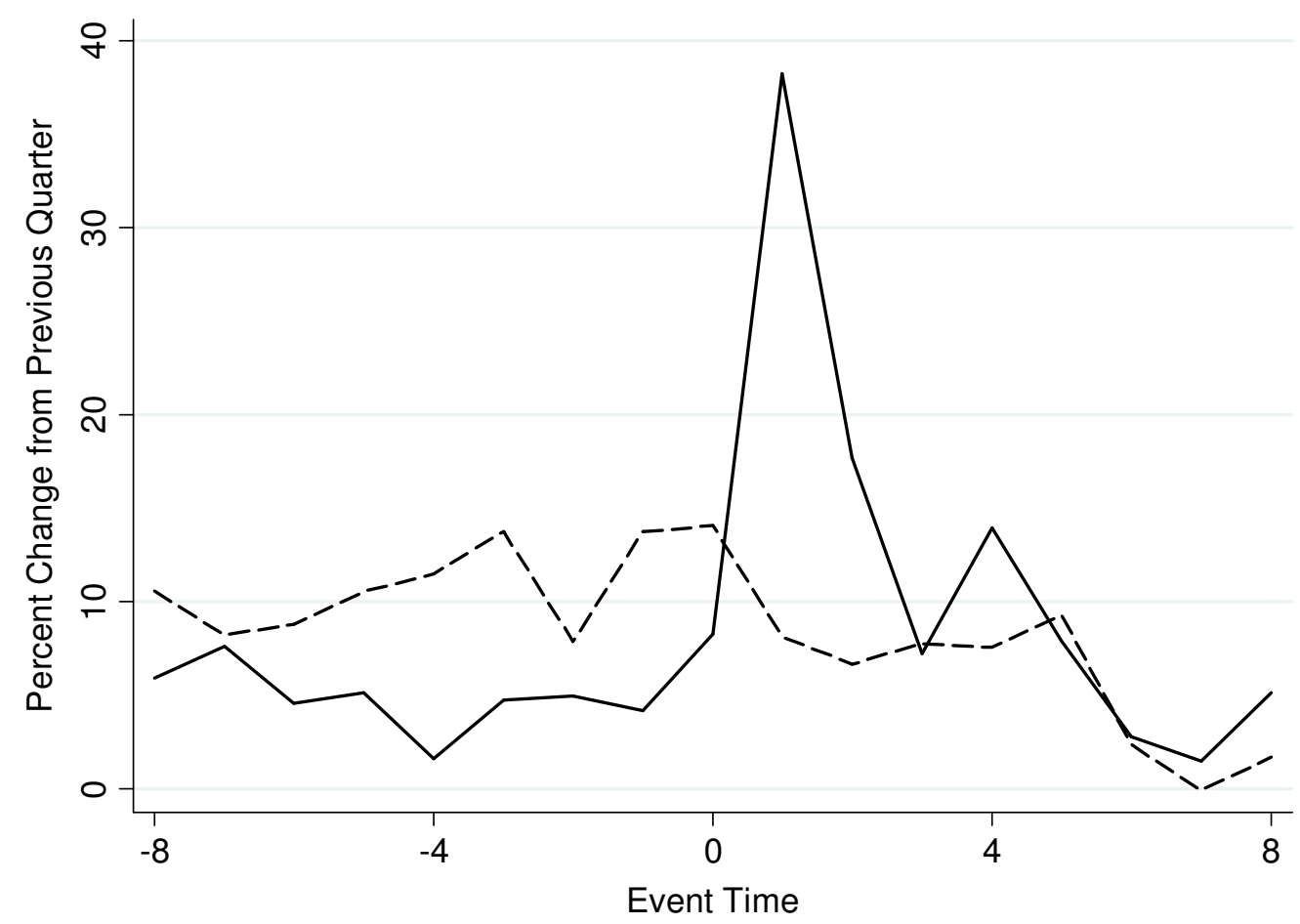


Figure 6. Time Bunching of Episodes

The figures depict the number of episodes in each month from January 1989 through December 2005.
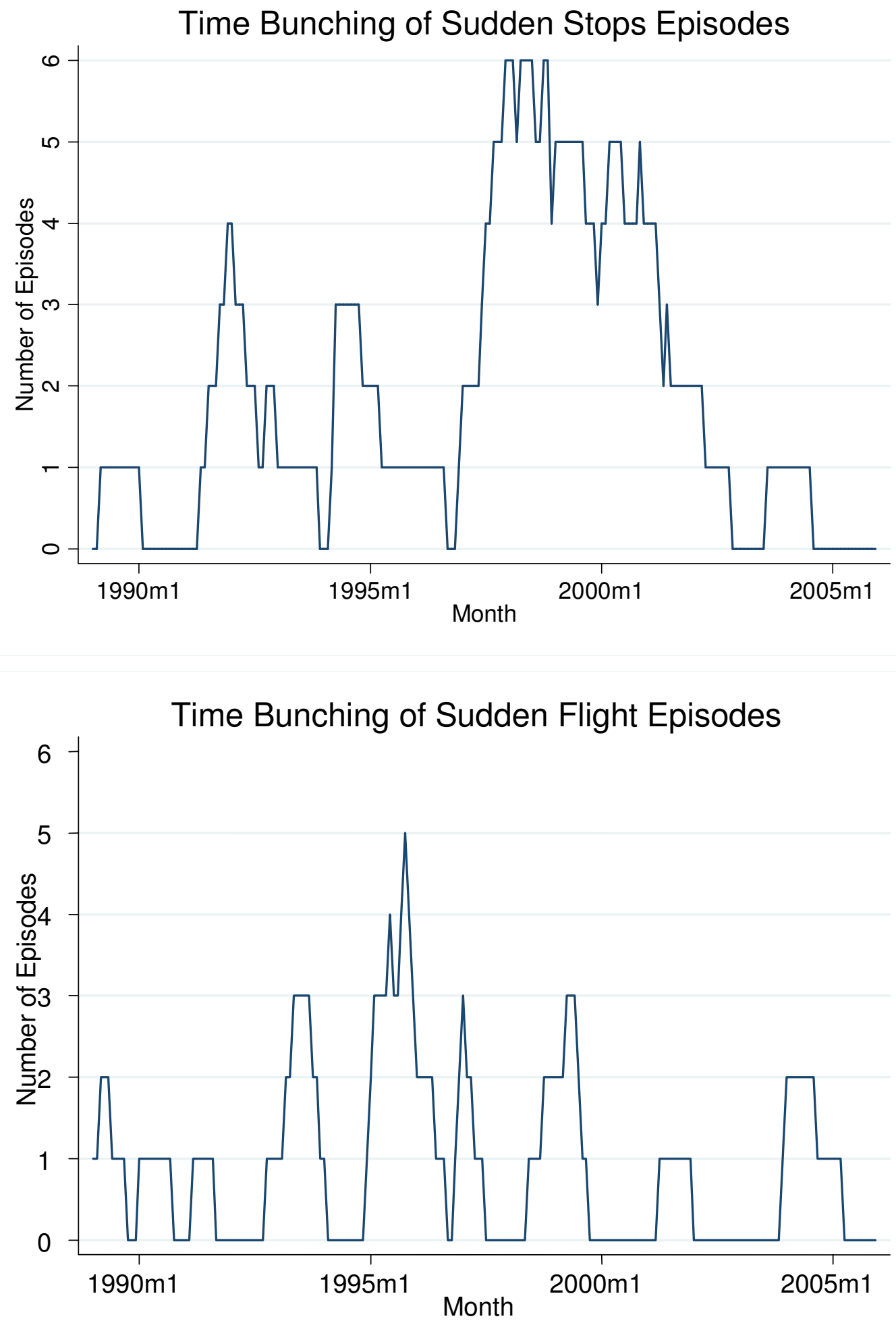